\title{
Cancer and other mortality patterns among United States furniture workers
}

\author{
B A MILLER, ' A E BLAIR,' H L RAYNOR, ${ }^{2 *}$ PATRICIA A STEWART, ${ }^{1}$ \\ SHEILA HOAR ZAHM,' J F FRAUMENI, JR'
}

From the Epidemiology and Biostatistics Program, ${ }^{1}$ Division of Cancer Etiology, National Cancer Institute, Bethesda, MD 20892, and United Furniture Workers of America, ${ }^{2}$ Nashville, TN 37210, USA

ABSTRACT Cause specific mortality was investigated among 36622 members of a national furniture workers' union who were first employed in unionised shops between 1946 and 1962. Overall mortalit for each race and sex group was less than expected when compared with United States death rates (white men SMR $=0 \cdot 8$, black men SMR $=0 \cdot 7$, white women SMR $=0 \cdot 8$, black women SMR $=$ 0.5 ); however, raised risks were observed among white men employed in specific types of furniturio industries and followed up for 20 or more years after first employment. Lymphatic ando haematopoietic cancers were significantly raised (SMR $=1.8$ ) among wood furniture workers followed up for at least 20 years due to excess deaths from leukaemia $(S M R=2.0)$ and non Hodgkin's lymphoma (SMR $=2 \cdot 0$ ). Mortality from acute myeloid leukaemia was particularly hig in this group (SMR $=4.7$ ) based on six observed cases. Metal furniture workers followed up for af least 20 years experienced a significant excess of all cancers combined $(S M R=1 \cdot 6)$, with non: significant increases in cancers of the lung, stomach, and colorectum. This group also had none significant excesses of liver cirrhosis, arteriosclerotic heart disease, and cerebrovascular disease. Nasal cancer was not found to be significantly raised in this cohort, though the average follow period may not have been sufficient to detect an excess risk for this uncommon tumour.

In the manufacture of various types of furniture there is potential for exposure to wood and metal dusts, wood preservatives, formaldehyde, adhesives, solvents, welding fumes, spray paint, stains, and lacquers. ${ }^{2}$ Toluene and xylene, commonly found in lacquers and paints, were frequently sampled in both wood and metal furniture plants inspected by the United States Occupational Safety and Health Administration (OSHA) between 1979 and 1987. ${ }^{3}$ Other solvents monitored by OSHA in wood furniture plants included benzene, ketones, petroleum distillates, acetates, and alcohols. Lead and oxides of copper, iron, and zinc were often measured in metal furniture shops and probably resulted from welding processes.

Adenocarcinoma of the nasal cavity and paranasal

\section{Accepted 26 September 1988}

*Present address: Amalgamated Clothing and Textile Workers' Union, New York, NY 10003. sinuses is a well documented occupational hazars among workers in the hardwood furniture industry based on numerous case-control studies and case reports, especially in Europe. ${ }^{14}$ There is also limite $\delta$ ' evidence for increased risk of cancers of the laryn $x^{5-\Phi}$ and lung, ${ }^{8-11}$ Hodgkin's disease, ${ }^{12-17}$ leukaemia, ${ }^{18-23}$ and lymphoma ${ }^{21-23}$ among workers in furniture and othe wood related industries. The availability of records. identifying members of a large, national furnitures worker union in the United States enabled us to conduct a cohort study to investigate associations between mortality and employment in this industro further.

\section{Methods}

A total of 36622 workers first employed in unionised shops between 1946 and 1962 was identified for studye from membership records maintained by the Unite Furniture Workers of America. This period included the earliest records consistently maintained by the union and allowed a minimum of 16 years of follow 
up. Mortality analyses were conducted on 22269 white men (WM), 5163 white women (WW), 4461 black men (BM), and 1283 black women (BW). The remainder of the cohort consisted of 3446 men and women of other or unknown race. Data available from the union records included each subject's name, social security number, sex, date of birth, address, date first employed in a unionised shop, shop name and job title at time of hire, and local union number. Complete work histories and termination dates were not available. The employment data were supplemented with information provided by union officials concerning the major products produced in shops named in the union records-for example, wood furniture, metal furniture, and other wood products. Product data and job titles were used for purposes of stratification in some of the analyses.

The vital status and race of cohort members were determined principally from information provided by the Social Security Administration. Additional sources of vital status information were records from the union's death benefits programme and from state motor vehicle departments. For those noted as dead, copies of official state death certificates were obtained and causes of death were coded by a nosologist using the 8th revision of the International Classification of Diseases (ICD) ${ }^{24}$ according to the rules in effect at the time of death.

Person-years were accumulated from the study entry date (date of employment in a unionised plant) until the date of death, the date lost to follow up, or until 1 January 1979, whichever occurred first. This last date was the most current cut off date for which vital status information was available on at least $90 \%$ of the total cohort. Expected numbers of deaths were computed from United States death rates with appropriate adjustments for age, race, sex, and calendar time using the software package developed by Monson. ${ }^{25}$ Expected numbers for specific leukaemia cell types, multiple myeloma, and lymphoma were derived from average age specific death rates among United States WM which were available for the period 1968-78. ${ }^{26}$ The standardised mortality ratio (SMR) was obtained by dividing the observed number of deaths by the expected number. Ninety five per cent confidence intervals (CI) for the SMR were calculated by Miettinen's test based method ${ }^{27}$ SMRs and CI were not calculated when both the observed and expected numbers of deaths for a specific cause were less than five. The effect of duration of follow up on the mortality experience of this cohort was also evaluated. Such analyses in other occupational mortality studies using general population comparison rates have shown that the SMR, initially low due to the "healthy worker effect," tends to increase during the first 10 to 20 years of follow up and level off thereafter..$^{28-30}$
Results

Cohort members worked in furniture plants and other related industries (table 1). Nearly two thirds of the cohort were employed in companies producing a variety of wood products including furniture, lumber, plywood, and crates. Workers in wood furniture shops accounted for $52 \%$ of this group. Metal products included furniture, bedsprings, and various metal parts. Workers in metal furniture plants accounted for $78 \%$ of this group. Other companies produced products made from wicker, paper, plastic, hair and felt, fur, foam, and textiles. A small portion of the cohort, classified under non-manufacturing, included product distributors and labour union staff. Information on type of industry was missing for less than $1 \%$ of the cohort and job titles were missing for $26 \%$ of the cohort.

Place of residence recorded in the union records indicated that study subjects were distributed among 37 states and the District of Columbia. Furniture workers in the states of North Carolina and Virginia were notably underrepresented in the cohort. Although these are major furniture producing states, their work forces were to a large extent not unionised and, therefore, not included in this study.

Vital status at 1 January 1979 was successfully ascertained for $96 \% \mathrm{WM}, 91 \% \mathrm{BM}, 90 \% \mathrm{WW}$, and $87 \% \mathrm{BW}$ in the cohort. Death certificates were located for 3437 WM $(92 \%$ of the total number of reported deaths), 567 BM (88\% of reported deaths), $392 \mathrm{WW}$ (88\% of reported deaths), and $79 \mathrm{BW}(87 \%$ of reported deaths). When death certificates could not be located, subjects were counted in the all causes of death category but were not assigned to any specific cause. Thus some of the cause specific SMRs may be slightly underestimated. There were 115 deaths reported among subjects whose last known residence was a foreign country and who are therefore believed to have died outside the United States. Since United States mortality statistics used for comparison in the analyses do not include foreign deaths, these subjects were not counted in the total number of deaths. For

Table 1 Distribution of cohort by type of product

\begin{tabular}{lcr}
\hline & $N o$ & $\%$ \\
\hline Wood products & 23481 & 64 \\
$\quad$ Wood furniture & $(12$ 259) & 12 \\
$\begin{array}{l}\text { Metal products } \\
\quad \text { Metal furniture }\end{array}$ & 4330 & 22 \\
Other* & $(3393)$ & 1 \\
Non-manufacturing & 8253 & $<1$ \\
Unknown & 342 & 100 \\
Total & 216 & \\
\hline
\end{tabular}

*Includes a variety of products made from wicker, paper, plastic, hair, felt, foam, and textiles. 
purposes of the analyses, person-years for these subjects were accumulated until their date of death.

Mortality among WM was significantly reduced (SMR $=0.8$ ) for all causes of death combined (table 2). Deficits occurred for most major causes of death including cancer, arteriosclerotic heart disease, cerebrovascular disease, non-malignant respiratory diseases, and accidents. Two nasal cancers were observed ( 1.8 expected) but no histological information was reported on the death certificates. Union records indicated that one of these cases worked in a wood furniture plant and the other in a chrome furniture plant at the time they enrolled in the union. Overall mortality was also significantly reduced among BM (SMR = 0.7; 95\% CI 0.6-0.8), WW (SMR $=0.8 ; 95 \%$ CI 0.7-0.8), and BW (SMR $=0.5 ; 95 \%$ CI $0.4-0.6)$ and is not shown in the table. Among each of these groups, observed numbers of deaths from major causes were less than expected numbers.

When the analyses were restricted to persons foll- owed up for at least 20 years, SMRs among WM were slightly raised for diabetes, kidney cancer, leukaemia, and non-Hodgkin's lymphoma, though these excesses were not statistically significant. SMRs were generally reduced among BM, WW, and BW followed up for at least 20 years. The observed number of deaths from leukaemia, however, exceeded the expected number among BM (3 observed $v 1.2$ expected) and WW (3 observed $v 1.6$ expected).

Subjects were grouped for the remaining analyses according to the type of furniture plant in which they is were employed at the time of enrolment in the union. Table 3 shows SMRs for WM in plants producing only wood furniture. Significant deficits occurred for all causes of death combined and all cancer deaths combined. The SMR was slightly raised for nonHodgkin's lymphoma. Among those followed up for at least 20 years, mortality remained less than expected for all causes of death and for all cancers, though the total number of deaths from cancer did not differ

Table 2 Mortality from cancer and other major causes of death among white men

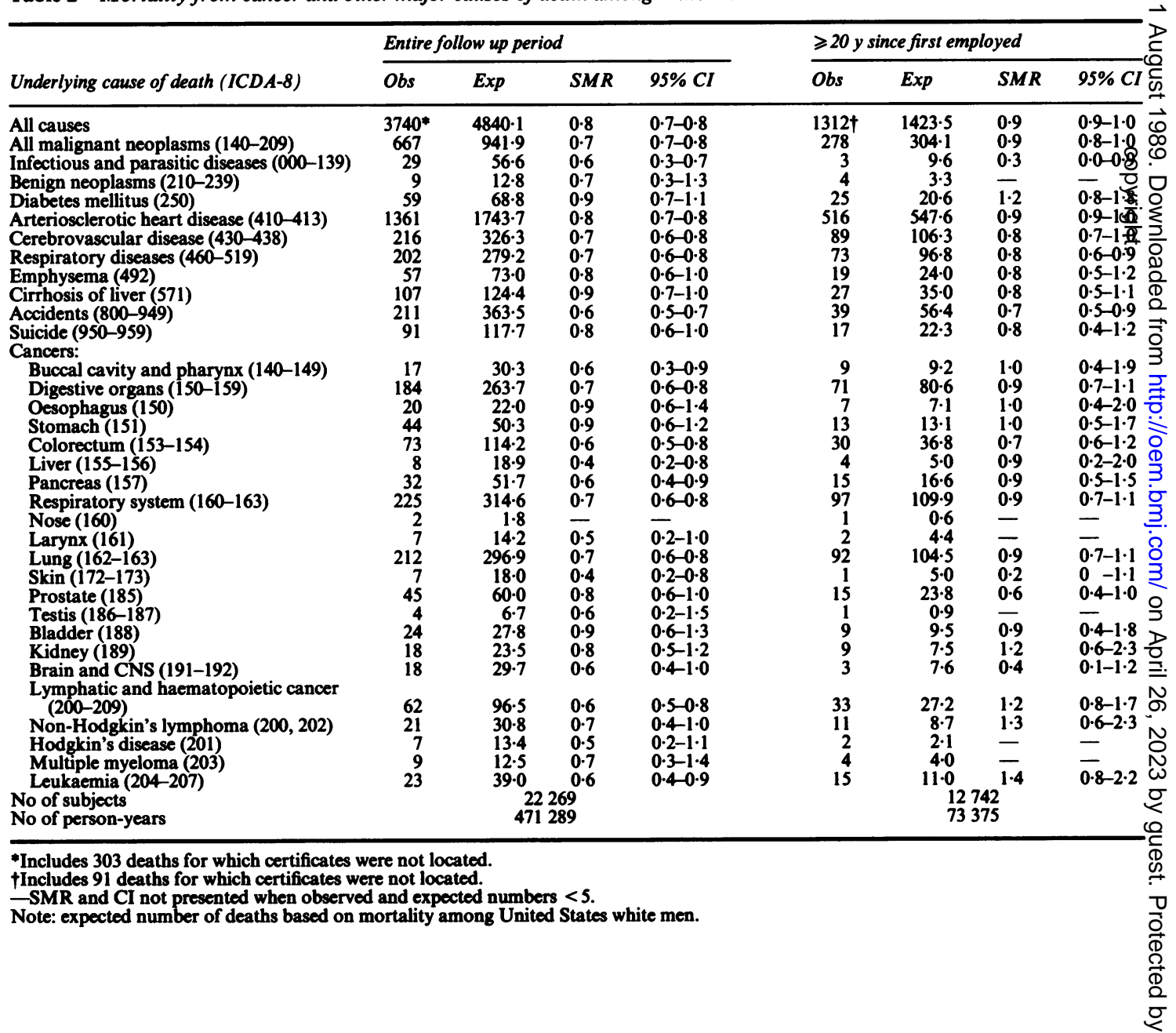


Table 3 Mortality from cancer and other major causes of death among white men: wood furniture plants

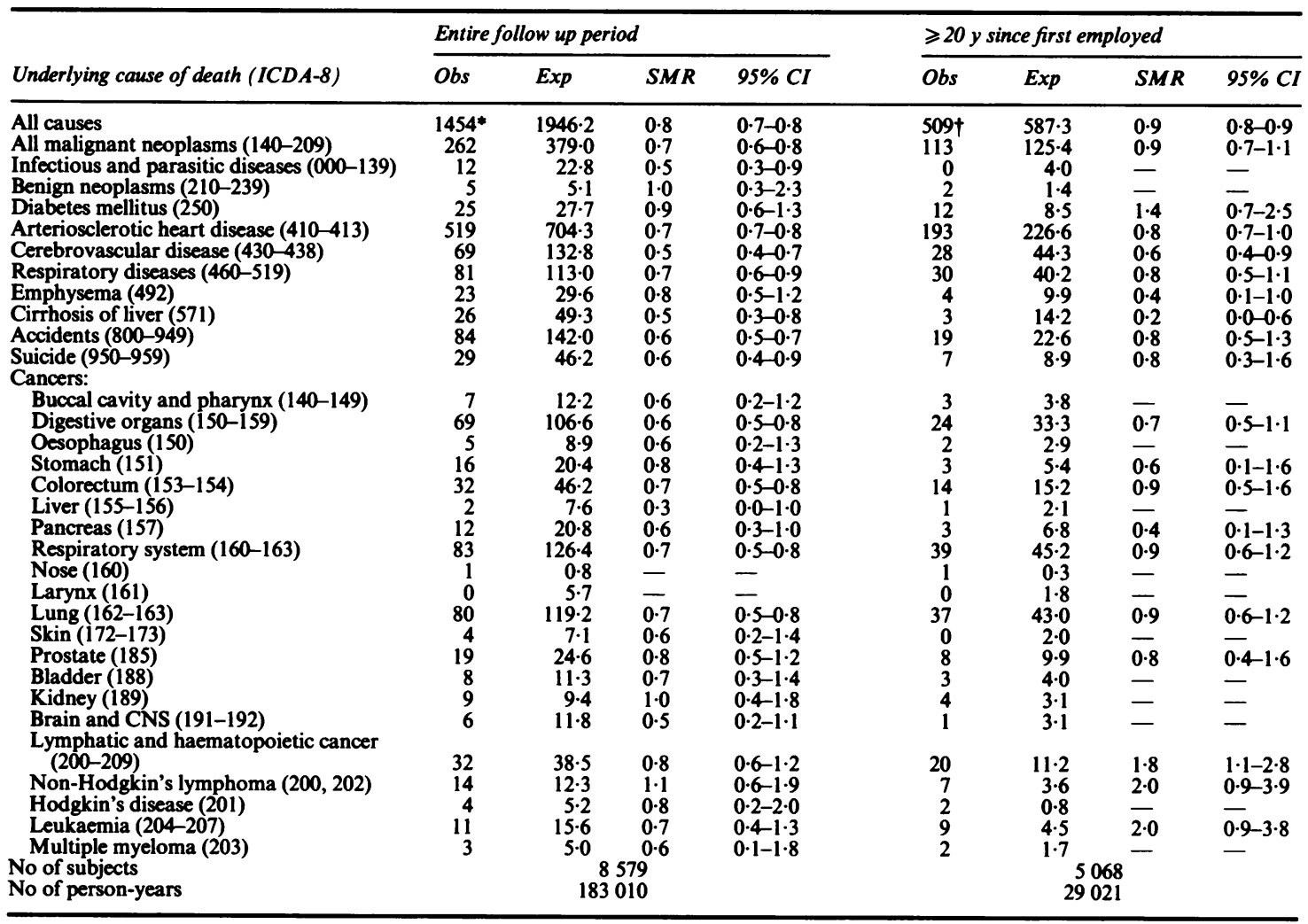

*Includes 121 deaths for which certificates were not located.

†Includes $\mathbf{4 0}$ deaths for which certificates were not located.

-SMR and CI not presented when observed and expected numbers $<5$.

Note: expected number of deaths based on mortality among United States white men.

significantly from the expected number. Deaths from lymphatic and haematopoietic cancers were significantly raised in this group (SMR $=1.8)$, with raised risks for leukaemia $(S M R=2 \cdot 0)$, non-Hodgkin's lymphoma (SMR $=2 \cdot 0)$, and Hodgkin's disease (2 deaths $v 0.8$ expected). The cell types of the nine leukaemias were recorded on the death certificates as acute myeloid ( 6 observed $v 1.3$ expected), chronic myeloid ( 1 observed $v 0.6$ expected), and one acute and one chronic leukaemia of unspecified type. The excess of acute myeloid leukaemia was statistically significant (SMR $=4 \cdot 7 ; 95 \%$ CI 1.9-9.8). One nasal cancer occurred among workers followed up for at least 20 years whereas the expected number was $0 \cdot 3$. Overall mortality and total cancer mortality was reduced among BM, WW, and BW in wood furniture plants, and no excess of leukaemia was detected in these groups. Analyses were limited, however, by the small number of deaths $(B M=138$ deaths, $\mathrm{WW}=120$ deaths, $\mathrm{BW}=18$ deaths).
Job titles were reviewed for deaths from lymphatic and haematopoietic cancer among wood furniture workers followed up for at least 20 years. The two deaths from Hodgkin's disease among WM occurred among workers in jobs with potential exposure to wood dust (1 sander, 1 finisher). There were two cabinet makers among the six deaths from acute myeloid leukaemia whereas the expected number was 0.4 , based on the frequency of this occupation among all white male wood furniture workers. Job titles among the four remaining deaths from acute myeloid leukaemia were finisher, general labourer, table packer, and unknown. Among the seven deaths from non-Hodgkin's lymphoma were two cabinet makers with 0.4 expected, whereas the remaining workers held jobs in finishing (2), sanding (1), upholstery (1), and bleaching (1).

Table 4 presents mortality for 2024 WM who worked in metal furniture plants. Unlike the wood furniture workers, observed numbers of deaths did not 
Table 4 Mortality from cancer and other major causes of death among white men: metal furniture plants

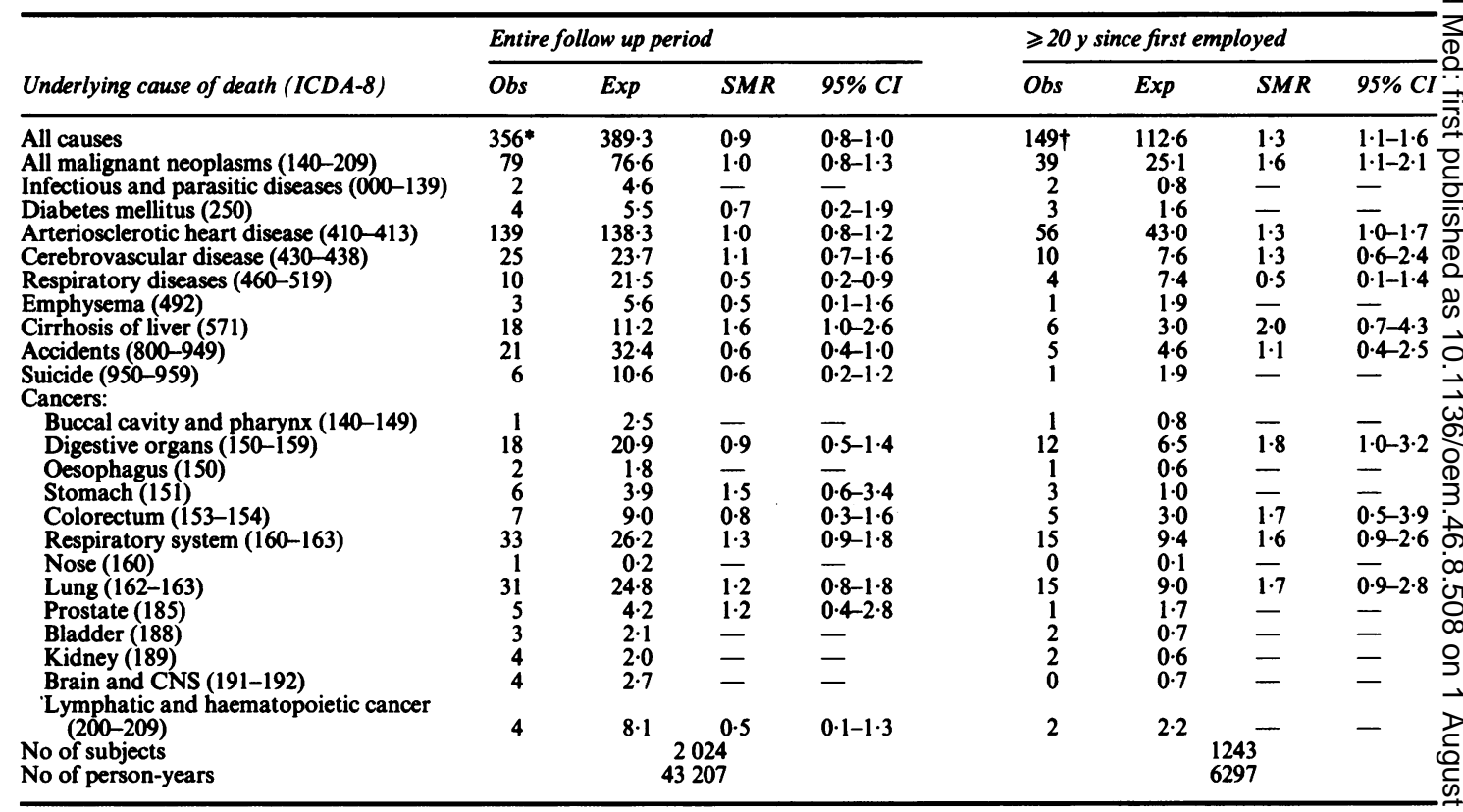

*Includes 18 deaths for which certificates were not located.

IIncludes eight deaths for which certificates were not located.

-SMR and CI not presented when observed and expected numbers $<5$.

Note: expected number of deaths based on mortality among United States white men.

differ significantly from expected numbers for all causes combined, all cancers combined, circulatory disease, and cerebrovascular disease. Mortality was significantly reduced for non-malignant respiratory disease $(\mathrm{SMR}=0.5)$ and accidents $(\mathrm{SMR}=0.6)$. Non-significant excesses were found for liver cirrhosis and cancers of the stomach, lung, and kidney. One nasal cancer was observed, as noted earlier, whereas the expected number was $\mathbf{0} \cdot 2$. When a minimum latency of 20 years was incorporated in the analysis, overall mortality was significantly raised $(\mathrm{SMR}=$ 1.3). This was due to excess deaths from cancer, arteriosclerotic heart disease, cerebrovascular disease, and hepatic cirrhosis. Cancer sites showing raised SMRs were the stomach, colorectum, and lung, though none of the increases was statistically significant. Mortality was not raised among metal furniture workers in other race/sex groups, though calculation of risk estimates for specific causes of death was not possible due to the small numbers (BM 110 deaths, WW 21, BW 4).

No unusual clusters of job titles were found among metal furniture workers within cause of death categories with raised SMRs with the exception of lung cancer. Among WM who died from lung cancer at least 20 years after the start of follow up were three painters $(0.4$ expected, based on the frequency of this occupation among all white male metal furnitu舫 workers) and two welders ( 0.7 expected).

Mortality patterns among other industry groups were generally reduced or not significantly different $\stackrel{\odot}{\complement}$ from expected values and are not presented.

\section{Discussion}

This study evaluated mortality patterns among Unitedo States workers in the furniture manufacturing indus- $-\frac{\mathbb{D}}{3}$ try, mainly to generate leads for further investigation. Numerous cause-specific mortality risks were com- 3 puted and as the number of statistical comparisonsi increases, the likelihood that some associations result from chance also increases. Several of the resultso reported here, however, are supported by findings from other studies.

The reduced overall mortality and total cancer mortality in this cohort were comparable with findingso from previous cohort studies of furniture workers in England, ${ }^{31}$ Denmark, ${ }^{32}$ and the United States. ${ }^{22}{ }^{330}$ Increases in certain site specific cancers were shown, $\sigma$ however, in subgroups of our study cohort. Most interesting was the significant excess of lymphatic ande haematopoietic cancer among white male wood fur- $-\frac{\Phi}{\infty}$ niture workers followed up for 20 or more years. An excess of Hodgkin's disease, although based on only- 
two deaths in our cohort, has been reported several times in association with woodworking industries. ${ }^{12-17}$ Hodgkin's disease has also been associated with exposure to chlorophenols, ${ }^{1534}$ a class of commonly used wood preservatives and fungicides. The increased leukaemia and lymphoma mortality is also consistent with other reports among woodworkers, ${ }^{18-23}$ with acute myeloid leukaemia being most notable among WM in our study. The slight excess of leukaemia among BM and WW was based on small numbers and was not related to a specific histology or type of furniture plant.

Exposure to benzene is a well documented cause of myeloid leukaemia ${ }^{35}$ and, although its use in the wood furniture industry has reportedly declined, ${ }^{12}$ OSHA inspection data indicate that some exposure to benzene still occurs in this industry. ${ }^{3}$ Our finding of increased lymphoma mortality among wood furniture workers is noteworthy in the light of potential exposures to xylene and other organic solvents. ${ }^{1-3} \mathrm{~A}$ small excess of lymphosarcoma was reported among rubber workers exposed to xylene ${ }^{36}$ and lymphoma was raised among workers exposed to organic solvents and chlorophenols. ${ }^{37} 38$

The number of person-years of observation in the present study were sufficient to detect a $4 \cdot 5$-fold excess of nasal cancer among the white male wood furniture workers; however, the median follow up of about 21 years may not have been long enough to detect raised mortality for this rare cancer. The mean latency for occupationally related nasal adenocarcinoma has been reported to be about 40 years, with a minimum observed latency of 27 years. ${ }^{39}$ Most cases of nasal cancer among furniture workers have been identified among workers first employed before the second world war. ${ }^{4}$ It has been suggested that this may be due either to an insufficient latency period for detecting cases among more recently exposed workers or to some change in workplace exposures. ${ }^{40}$ The present study focused on furniture workers employed after 1945. Union records indicated that the one wood furniture worker who died from nasal cancer was first employed in a unionised shop in 1955 and died in 1977 at the age of 46.

Results from studies of United States furniture workers indicate that, whereas a significant excess of nasal adenocarcinoma exists, it is smaller than that generally reported in the European furniture industry. ${ }^{41-43}$ Although this observation remains unexplained, several reasons have been suggested. These include differences between the United States and European industries with respect to the dust levels, types of wood used, chemicals or other additives present in the wood, and manufacturing methods which may result in qualitative differences in workplace exposures. ${ }^{4}$
Mortality from cancers of the lung and larynx was less than expected among wood furniture workers in this cohort, although associations have been suggested by occupational studies of these tumours. ${ }^{5-11}$ Reduced incidence of these cancers was also noted among furniture workers in Sweden, ${ }^{44}$ whereas a recent survey of respiratory cancer in the Finnish wood industry showed raised risks that appeared related to exposure to pesticides and phenol. ${ }^{45}$

Among metal furniture workers, raised mortality was observed for cancers of the lung, stomach, and colorectum and cirrhosis of the liver. Interpretations are clouded by the small numbers and limited work history information, although exposures have been reported to metal dusts, spray paints, and solvents. ${ }^{1-3}$ Previous studies have reported excess lung cancer mortality among workers in metal industries, ${ }^{46}$ welders $^{1147}$ and painters. ${ }^{18203348-55}$ Increased mortality from hepatic cirrhosis has been noted among furniture workers ${ }^{21}$ and marine inspectors potentially exposed to a variety of solvents. ${ }^{5 s}$

Caution must be used when interpreting the mortality patterns due to the lack of information on smoking habits and alcohol use. It is unlikely, however, that the excess of lung cancer among the metal furniture workers is due to heavier smoking. The reduced mortality from emphysema and slight rise in arteriosclerotic heart disease among the metal furniture workers suggests that their smoking habits were similar to those of the comparison population of United States WM. Independent data indicate that approximately $60 \%$ of United States furniture workers have smoked cigarettes at some time, ${ }^{21} 56$ whereas the percentage of all United States men who had ever smoked was slightly higher, at $70 \%$, in a 1976 national survey. ${ }^{57}$ In addition, several occupational mortality surveys which included smoking data on individuals indicated that most occupational associations with lung cancer remained unchanged after adjusting for cigarette smoking. 4955589

The association between hepatic cirrhosis and work in the metal furniture industry is difficult to interpret in the absence of information on alcohol consumption. Ten of the 18 deaths in this group were noted on death certificates as being alcohol related; however, deaths attributed to alcoholism (ICD code 303) were not raised. Furthermore, oral and oesophageal cancers, also related to alcohol consumption, were not increased among the metal furniture workers.

The value of job title information was limited in this study, since it pertained only to the job at the time of hire by a unionised shop and was missing for $26 \%$ of the cohort. The lack of detailed work history information may lead to misclassification of individuals by exposure with resulting dilution of risks. In such situations a subgroup of workers who are at high risk 
may be overlooked. It was also not possible to evaluate associations with duration of employment, since the date of termination of employment was not available. Thus it was not possible to investigate underlying trends between employment history and mortality risks which may be masked by the strong healthy worker effect observed in this cohort.

Despite the limitations of this cohort study of furniture workers, there were several findings that deserve additional study. Of special interest was the excess mortality from leukaemia, Hodgkin's disease, and non-Hodgkin's lymphoma among wood workers. Furthermore, metal furniture workers showed increased risks for cancers of the lung, stomach, and large bowel. The associations with cancer and other diseases such as cirrhosis in the furniture industry should prompt further epidemiological and aetiological investigations.

\section{References}

1 International Agency for Research on Cancer. Monographs on the evaluation of the carcinogenic risk of chemicals to humans. Vol 25. Wood leather, and some associated industries. Lyon: IARC, 1981.

2 Dyson WL. Furniture manufacturing: a step-by-step profile. Occupational Health Safety 1981;50:23-30.

3 US Department of Labor, Occupational Safety and Health Administration. Integrated management information system, 1979-87. Washington: US Department of Labor, 1987.

4 Imbus HR, Dyson WL. A review of nasal cancer in furniture manufacturing and woodworking in North Carolina, the United States, and other countries. J Occup Med 1987;29: 734-40.

5 Wolf $O$. Occupational and nonoccupational factors involved in laryngeal cancer. $Z$ Gesamte Hyg 1978;24:174-7.

6 Wynder EL, Covey LS, Mabuchi K, Mushinswki M. Environmental factors in cancer of the larynx. Cancer 1976;38: 1591-1601.

7 Brown LM, Mason TJ, Pickle LW, et al. Occupational risk factors for laryngeal cancer on the Texas Gulf coast. Cancer Res 1988; 48:1960-4.

8 Esping B, Axelson $\mathbf{O}$. A pilot study on respiratory and digestive tract cancer among woodworkers. Scand J Work Environ Health 1980;6:201-5.

9 Blot WJ, Davies JE, Brown LM, et al. Occupation and the high risk of lung cancer in northeast Florida. Cancer 1982;50: 364-71.

10 Siemiatycki J, Richardson L, Gerin M, et al. Associations between several sites of cancer and nine organic dusts: results from an hypothesis-generating case-control study in Montreal, 1979 1983. Am J Epidemiol 1986;123:235-49.

11 Ronco G, Ciccone G, Mirabelli D, Trola B, Vineis P. Occupation and lung cancer in two industralized areas of northern Italy. Int J Cancer 1988;41:354-8.

12 Acheson ED. Hodgkin's disease in woodworkers. Lancet 1967; ii:988-9.

13 Milham S Jr, Hesser JE. Hodgkin's disease in woodworkers. Lancet 1967;ii:136-7.

14 Petersen GR, Milham S Jr. Hodgkin's disease mortality and occupational exposure to wood. J Natl Cancer Inst 1974;53:
957-8.

15 Greene MH, Brinton LA, Fraumeni JF Jr D'Amico R. Familial and sporadic Hodgkin's disease associated with occupational wood exposure. Lancet 1978;ii:626-7.

16 Grufferman S, Duong T, Cole P. Occupation and Hodgkin's:disease. J Natl Cancer Inst 1976;59:1193-5.

17 Milham S Jr. A study of the mortality experience of the AFL-CIO United Brotherhood of Carpenters and Joiners of America, 1969-1970. Springfield, VA: National Technical Information 흐 Service, 1974. (DHEW publ No (NIOSH) 74-129.)

18 Dubrow R, Wegman DH. Cancer and occupation in Massa- $\vec{\nabla}$ chusetts: a death certificate study. Am J Ind Med 1984;6: 207-30.

19 Morton W, Marjanovic D. Leukemia incidence by occupation in the Portland-Vancouver metropolitan area. Am J Ind Med $\vec{O}$ 1984;6:185-205.

20 Petersen GR, Milham S Jr. Occupational mortality in the state of $\vec{\omega}$ California 1959-61. Cincinnati: National Institute for Occupational Safety and Health, 1980. (DHEW publ No (NIOSH) 80-104.)

21 Walrath J, Rogot E, Murray J, Blair A. Mortality patterns among " US veterans by industry and smoking status. Bethesda, MD:O National Institutes of Health, 1985. (NIH publ No 85-2747.)

22 Stellman SD, Garfinkel L. Cancer mortality among woodworkers. O Am J Ind Med 1984;5:343-57.

23 Robinson C, Waxweiler RJ, McCammon CS. Pattern and modelo makers, proportionate mortality 1972-1978. Am J Ind $\mathrm{Med}^{\supset}$ 1980;1:159-65.

24 US Department of Health Education and Welfare. Eighth revision international classification of diseases adapted for use in the United States. Washington: Public Health Service, 1967. (PHS क publ No 1693.)

25 Monson RR. Analysis of relative survival and proportional $\vec{\varphi}$ mortality. Comput Biomed Res 1974;7:325-32.

26 Pickle LW, Mason TJ, Howard N, Hoover R, Fraumeni JF 8 Atlas of US cancer mortality among whites: 1950-1980. Washington: US Government Printing Office, 1987. (DHeSs publ No (NIH) 87-2900.)

27 Miettinen OS. Estimability and estimation in case-referent studies. Am J Epidemiol 1976;103:226-35.

28 Monson RR. Observations on the healthy worker effect. J Occup Med 1986;28:425-33.

29 Fox AJ, Collier PF. Low mortality rates in industrial cohort studies due to selection for work and survival in the industry. Br J Prev Soc Med 1976;30:225-30.

30 McMichael AJ. Standardized mortality ratios and the "healthyo" worker effect": scratching beneath the surface. J Occup Med 1976;18:165-8.

31 Acheson ED, Pippard EC, Winter PD. Mortality of English furniture makers. Scand J Work Environ Health 1984;10: 211-7.

32 Olsen J, Sabroe S. A follow-up study of non-retired and retired members of the Danish carpenter/cabinet makers' trade union. Int J Epidemiol 1979;8:375-82.

33 Guralnick L. Mortality by industry and cause of death among men $\bigcirc$ 20 to 64 years of age: United States, 1950. Washington: Public Health Service, 1963. (Vital statistics-special reports 53.) D

34 Hardell L, Bengtsson NO. Epidemiological study of socioeconomic factors and clinical findings in Hodgkin's disease, $\bar{N}$ and reanalysis of previous data regarding chemical exposure. O Br J Cancer 1983;48:217-25.

35 Heath CW Jr. The leukemias. In: Schottenfeld D, Fraumeni JF Jr, eds. Cancer epidemiology and prevention. Philadelphia: WB $\mathrm{W}$ Saunders, 1982:728-38.

36 Wilkosky TC, Checkoway H, Marshall EG, Tyroler HA. Cancer mortality and solvent exposures in the rubber industry. $A m I n d$ 을 Hyg Assoc J 1984;45:809-11.

37 Hardell L, Eriksson M, Lenner P, Lundgren E. Malignant lymphoma and exposure to chemicals, especially organic $\square$ solvents, chlorophenols and phenoxy acids: a case-control

.

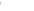

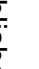



study. Br J Cancer 1981;43:169-76.

38 Vianna NJ, Polan A. Lymphomas and occupational benzene exposure. Lancet 1979;i:1394-5.

39 Acheson ED. Nasal cancer in furniture workers: the problem. In: The carcinogenicity and mutagenicity of wood dust. Southampton: Medical Research Council, 1982. (Sci report No 1.)

40 Hayes R, Gerin M, Raatgever JW, De Bruyin A. Wood-related occupations, wood dust exposure, and sinonasal cancer. Am J Epidemiol 1986;124:569-77.

41 Brinton LA, Blot WJ, Becker JA, et al. A case-control study of cancers of the nasal cavity and paranasal sinuses. Am $J$ Epidemiol 1984;119:896-906.

42 Roush GCV, Meigs JW, Kelly J. Sinonasal cancer and occupation: a case-control study. Am J Epidemiol 1980;111:183-93.

43 Brinton LA, Blot WJ, Stone BJ. A death certificate analysis of nasal cancer among furniture workers in North Carolina. Cancer Res 1977;37:3473-4.

44 Gerhardsson MA, Norell SE, Kiviranta HJ, Ahlbom A. Respiratory cancers in furniture workers. Br J Ind Med 1985;42:403-5.

45 Kauppinen TP, Partanen TJ, Nurminen MM, et al. Respiratory cancers and chemical exposures in the wood industry: a nested case-control study. Br J Ind Med 1986;43:84-90.

46 International Agency for Research on Cancer. Monographs on the evaluation of carcinogenic risk of chemicals to humans, Vol 23. Some metals and metallic compounds. Lyon: IARC, 1980.

47 Beaumont J, Weiss N. Lung cancer among welders. J Occup Med 1981;23:839-44.

48 Dalager NA, Fraumeni JF Jr, Hoover R, Mason T, Payne WW. Cancer mortality among workers exposed to zinc chromate paints. J Occup Med 1980;22:25-9.

49 Decoufle P, Stanislawczyk K, Houten L, Bross IDJ, Viadana E. $A$ retrospective survey of cancer in relation to occupation.
Cincinnati: US Department of Health, Education, and Welfare, 1977. (DHEW(NIOSH) publ No 77-178.)

50 Englund A. Cancer incidence among painters and some allied trades. J Toxicol Environ Health 1980;6:1267-73.

51 Menck HR, Henderson BE. Occupational differences in rates of lung cancer. J Occup Med 1976;18:797-801.

52 Milham S. Occupational mortality in Washington State 1950-1979. Cincinnati: National Institute for Occupational Safety and Health, 1983. (DHHS(NIOSH) publ No 83-116.)

53 Milne KL, Sandler DP, Everson RB, Brown SM. Lung cancer and occupation in Alameda County: a death certificate casecontrol study. Am J Ind Med 1983;4:565-75.

54 Registrar General. Decennial supplement for England and Wales, 1970-72. Occupational mortality. London: HMSO, 1978.

55 Williams RR, Stegens NL, Goldsmith JR. Associations of cancer site and type with occupation and industry from the third national cancer survey interview. J Natl Cancer Inst 1977; $59: 1147-85$

55a Blair A, Haas T, Prosser R, et al. Mortality among United States Coast Guard marine inspectors. Arch Environ Health (in press).

56 Brackbill R, Frazier T, Schilling S. Smoking characteristics of US workers, 1978-1980. Am J Ind Med 1987;13:5-41.

57 US Department of Health, Education and Welfare. Use habits among adults of cigarettes, coffee, aspirin, and sleeping pills. United States, 1976. Hyattsville, MD: National Center for Health Statistics, 1979. (DHEW publ No (PHS)80-1559.)

58 Blair A, Hoar SK, Walrath J. Comparison of crude and smokingadjusted standardized mortality ratios. J Occup Med 1985; 27:881-4.

59 Bross IDJ, Viadana E, Houten L. Occupational cancer in men exposed to dust and other environmental hazards. Arch Environ Health 1978;33:300-7.

\section{Destruction of manuscripts}

From 1 July 1985 articles submitted for publication will not be returned. Authors whose papers are rejected will be advised of the decision and the manuscripts will be kept under security for three months to deal with any inquiries and then destroyed. 